\title{
Influence of an Extract of Juglans regia on the Growth of Escherichia coli, on the Electrophoretic Profile of Plasmid DNA and on the Radiolabeling of Blood Constituents
}

\author{
Sebastião David Santos-Filho ${ }^{1 *}$, Claudia Leite Diniz ${ }^{1}$, Fernanda Santos do Carmo ${ }^{1}$, \\ Adenilson de Souza da Fonseca ${ }^{1,2}$ and Mario Bernardo-Filho ${ }^{1,3}$ \\ ${ }^{I}$ Departamento de Biofísica e Biometria; Instituto de Biologia Roberto Alcantara Gomes; Universidade do Estado \\ do Rio de Janeiro; Av. 28 de Setembro, 87; 20551030; Rio de Janeiro - RJ - Brasil; santos-filho@ uer.br. ${ }^{2}$ Centro \\ de Ciências da Saúde; Centro Universitário Serra dos Órgãos; Av. Alberto Torres, 111; 25964004; Teresópolis - \\ RJ - Brasil. ${ }^{3}$ Instituto Nacional do Câncer; Coordenadoria de Pesquisa Básica; Praça Cruz Vermelha, 23; \\ 20230130; Rio de Janeiro - RJ - Brasil
}

\begin{abstract}
The aim of this work was to study the influence of a walnut (Juglans regia) extract on the growth of Escherichia coli (E. coli) AB1157, on the plasmid DNA topology and on the labeling of blood constituents with technetium-99m $\left({ }^{99 m} T c\right)$. An E. coli AB1157 culture, in stationary phase, was incubated with walnut and the growth of the culture was evaluated by optical density at $600 \mathrm{~nm}$ for 7 hours. Plasmid DNA samples were incubated with $\mathrm{SnCl}_{2}$ in presence or absence of walnut for 40 minutes, $0.8 \%$ agarose gel electrophoresis was performed, the gel was stained and the plasmid topological forms were visualized. Blood samples from Wistar rats were incubated with walnut extract and an assay of labeling of blood constituents with technetium-99m $\left({ }^{99 m} \mathrm{Tc}\right)$ was performed. Blood cells and plasma were separated. The radioactivity in each fraction was counted and percentage of incorporated radioactivity (\%ATI) was determined. The results presented an inhibitory action of the growth of the E. coli AB1157 culture, no protective action of the walnut extract in plasmid DNA treated with $\mathrm{SnCl}_{2}$. Moreover, walnut was also not capable to induce modifications in the DNA mobility in agarose gel but walnut was capable to decrease the distribution of ${ }^{99 m}$ Tc on the blood cell compartment. In conclusion, our experimental data suggest that in the walnut extract has substances with an effect on the growth of E. coli culture, a potential action to increase the $\mathrm{SnCl}_{2}$ effect on plasmid DNA and also is capable to alter the distribution of ${ }^{99 m}$ Tc on the blood cell compartment probably due to redoxi properties.
\end{abstract}

Keywords: Escherichia coli, DNA, Electrophoresis, Stannous chloride, Technetium-99m, Juglans regia

\section{INTRODUCTION}

The use of natural products, as medicinal plants, has increased and it is very frequent worldwide. Walnut (Juglans regia) has been widely used as an herbal medicine in the treatment for diabetes (Asgary et al., 2008). This natural product has been also used in folk medicine to treat prostate and vascular disturbs (Spaccarotella et al., 2008). Walnut also has high anti-atherogenic potential

\footnotetext{
* Author for correspondence
} 
and a remarkable osteoblastic activity that implicates on the beneficial effect of a walnutenriched diet on cardioprotection and bone loss (Papoutsi et al., 2008). The cardiovascular protective effect of a walnut diet has been related to antioxidant and hypocholesterolaemic effects as well as via modulation of endothelial function (Tsuda and Nishio, 2004). Walnut extracts have been exhibited antioxidant capacity in a concentration-dependent manner in different performed assays. Their antimicrobial capacity was also checked against different gram positive and gram negative bacteria, and fungi, revealing activity against the different tested microorganisms (Pereira et al., 2008).

Free radicals are highly reactive species of molecules that could be generated by some oxidative cellular mechanisms (Infanger et al, 2006). If these molecules are produced in excess, they could induce tissue damage. There are internal mechanisms in the living organisms constituted by enzymes and other molecules to try to protect the cells against the action of these free radicals (Hsieh et al, 2005; Kinoshita et al, 2005; Bao and Lou, 2006; Marcus et al, 2006). In addition to these defense mechanisms, certain medicinal compounds, including vitamins and other nutrition products could inhibit the production of free radicals (Infanger et al, 2006).

Stannous chloride $\left(\mathrm{SnCl}_{2}\right)$ is the most used reducing agent in nuclear medicine to label cellular and molecular structures with biological interest with technetium- $99 \mathrm{~m}\left({ }^{99 \mathrm{~m}} \mathrm{Tc}\right)$ to be used as radiobiocomplexes (Bernardo-Filho et al, 2005). In vitro red blood cells labeled with ${ }^{99 \mathrm{~m}} \mathrm{Tc}$ has been proposed as an assay to assess biological effects of natural and synthetic drugs (Fonseca et al., 2007; Benarroz et al., 2008).

Some authors have performed studies about the citotoxic/genotoxic potentials of $\mathrm{SnCl}_{2}$ (BernadoFilho et al, 1994; Pungartnik et al, 2005; Almeida et al, 2007). Using bacterial cultures and plasmid DNA has been suggested that stannous chloride appears to induce damages in the deoxyribonucleic acid (DNA) by oxidative mechanisms related to free radicals generation (Dantas et al., 2002; ElDemerdash et al, 2005). Data from assays with Escherichia coli (E. coli) deficient in DNA repair mechanisms suggested that this chemical agent could induce different lesions in DNA (ElDemerdash et al, 2005; Almeida et al, 2007).

The aim of this work was to study the influence of a walnut extract on the growth of Escherichia coli $\mathrm{AB} 1157$, on the electrophoretic profile of plasmid DNA and on the labeling of blood constituents with ${ }^{99 \mathrm{~m}} \mathrm{Tc}$.

\section{MATERIALS AND METHODS}

\section{Preparation of the extract}

The extract of walnut was prepared with $50 \mathrm{mg}$ of a macerate of Juglans regia (Chá and Cia Produtos Naturais, Brazil, lot A-1000/1, validity $06 / 20 / 2009$ ) in $10 \mathrm{ml}$ of $0.9 \% \mathrm{NaCl}$ (saline). The preparation was homogenized $(1 \mathrm{~min})$ in a vortex mixer and centrifuged at $2000 \mathrm{rpm} / 10 \mathrm{~min}$ and $1 \mathrm{ml}$ of the supernatant was considered to contain $5 \mathrm{mg}$ of the walnut extract. The quality control of this extract was evaluated with the analysis of the absorption spectra of walnut extract recorded in the range from 400 up to $700 \mathrm{~nm}$ with intervals of $20 \mathrm{~nm}$ using a spectrophotometer (Analyser $800 \mathrm{M}$, Analyser Comércio e Indústria LTDA, São Paulo, Brazil), using a cuvette of $1 \mathrm{~cm}$ pathlength. All spectrophotometric measurements were performed on the same spectrophotometer and the value of the absorbance $(0.212 \pm 0.037)$ at $480 \mathrm{~nm}$ was used as marker and the reproducibility control of each prepared walnut in the all experiments.

\section{Bacterial cultures}

E. coli AB1157, a wild-type strain, proficient to repair damage in the DNA, was used in this work. From stock (in glycerol $50 \% \mathrm{v} / \mathrm{v})$, a sample $(50 \mu \mathrm{l})$ of the culture was grown on liquid LB medium (5ml, Luria and Burrous, 1957) at $37^{\circ} \mathrm{C}$ overnight on a shaking water bath (reciprocal water bath shaker, model R76, New Brunswick, USA) up to the stationary growth phase.

\section{Bacterial growth assay}

A sample $(150 \mu \mathrm{l})$ was taken from $E$. coli AB11557 in stationary phase and incubated on the shaking water bath with (i) $15 \mathrm{ml}$ of LB medium and $1.5 \mathrm{ml}$ of saline, or (ii) $15 \mathrm{ml}$ of LB medium and $1.5 \mathrm{ml}$ of walnut extract $(5 \mathrm{mg} / \mathrm{ml})$, or (iii) 15 $\mathrm{ml}$ of $\mathrm{LB}$ medium and $1.5 \mathrm{ml}$ of walnut extract $(0.31 \mathrm{mg} / \mathrm{ml})$, at $37^{\circ} \mathrm{C}$. Saline was used as control. The growth of the E. coli was evaluated by optical density at $600 \mathrm{~nm}$ using aliquots $(1 \mathrm{ml})$ separated at zero, 30, 60, 90, 120, 150, 180, 210, 240, 300, 360 , and $420 \mathrm{~min}$. 


\section{Analysis of electrophoretic profile of DNA}

Preparation of plasmids was performed using alkaline method, described by Sambroock et al (1989). Experiments were done with plasmid (pBSK) DNA (200ng) incubated with walnut extract at different concentrations. Aliquots were also incubated with $200 \mu \mathrm{g} / \mathrm{ml}$ of $\mathrm{SnCl}_{2}$ in order to evaluate the influence of walnut extract on the DNA lesions induced by stannous ion. The experiments were carried out at room temperature and plasmid DNA aliquots were incubated with (1) saline, as a control, (2) $\mathrm{SnCl}_{2}(200 \mu \mathrm{g} / \mathrm{ml})$, (3) walnut $5 \mathrm{mg} / \mathrm{ml}$, (4) walnut $0.5 \mathrm{mg} / \mathrm{ml}$, (5) walnut $0.05 \mathrm{mg} / \mathrm{ml}$, (6) walnut $5 \mathrm{mg} / \mathrm{ml}$ and $\mathrm{SnCl}_{2}$ $(200 \mu \mathrm{g} / \mathrm{ml})$, (7) walnut $0.5 \mathrm{mg} / \mathrm{ml}$ and $\mathrm{SnCl}_{2}$ $(200 \mu \mathrm{g} / \mathrm{ml})$, (8) walnut $0.05 \mathrm{mg} / \mathrm{ml}$ and $\mathrm{SnCl}_{2}$ $(200 \mu \mathrm{g} / \mathrm{ml})$, for $40 \mathrm{~min}$. Aliquots of each sample $(10 \mu \mathrm{l})$ were mixed. Aliquots of each sample (10 $\mu 1)$ were mixed to $1 \mu \mathrm{l}$ of $6 \mathrm{x}$ concentrated loading buffer $\quad(0.25 \%$ xylene cyanol FF, $0.25 \%$ bromophenol blue, $30 \%$ glycerol in water), applied in a horizontal gel electrophoresis chamber (7 $\mathrm{V} / \mathrm{cm}$ ) in Tris-acetate-EDTA buffer at $\mathrm{pH} 8.0$ and the electrophoresis was performed. Following, the gel was stained with ethidium bromide $(0.5 \mu \mathrm{g} / \mathrm{ml})$, the DNA bands were visualized by fluorescence in an ultraviolet transilluminator system and the gel was recorded using a digitalization system.

\section{In vitro radiolabeling of blood constituents}

Samples $(0.5 \mathrm{~mL})$ of whole blood $(\mathrm{n}=4$, for each walnut concentration), withdrawn from Wistar rats, were incubated with this extract at different concentrations $(0.0,0.31,0.62,1.25,2.5,5 \mathrm{mg} / \mathrm{ml}$; 1 hour). After that, $\mathrm{SnCl}_{2}(1.2 \mu \mathrm{g} / \mathrm{mL}, 1$ hour $)$ was added and, in sequence, ${ }^{99 \mathrm{~m}} \mathrm{Tc}(3.7 \mathrm{MBq}, 10$ minutes) as sodium pertechnetate $\left(\mathrm{Na}^{99 \mathrm{~m}} \mathrm{TcO}_{4}\right)$, recently milked from a ${ }^{99} \mathrm{Mo} /{ }^{99 \mathrm{~m}} \mathrm{Tc}$ generator (Instituto de Pesquisas Energéticas e Nucleares, Comissão Nacional de Energia Nuclear, São Paulo, Brazil). These samples were centrifuged (1500 rpm, 5 minutes) and plasma $(\mathrm{P})$ and blood cells (BC) were separated. The radioactivity (\% ATI) in $\mathrm{P}$ and $\mathrm{BC}$ was determined in a well gamma counter (Packard, model C5002, Illinois, USA). The \%ATI was calculated as described previously (Bernardo-Filho et al., 1983).

\section{Statistical analysis}

Data are reported as (means $\pm \mathrm{SD}$ ) of the \%ATI and the percentual of plasmid forms. The One-way analysis of variance-ANOVA test was performed to verify possible statistical differences $p<0.05$ as less significant level.

\section{RESULTS}

The Figure 1 shows the absorption spectrum of the walnut extract used in the experiments. The pattern of the absorption spectrum presents, in these conditions the highest measure of the optical density $(0.212 \pm 0.037)$ at $480 \mathrm{~nm}$. This parameter has allowed to control the experimental conditions of preparation of the extracts and was used as a marker.

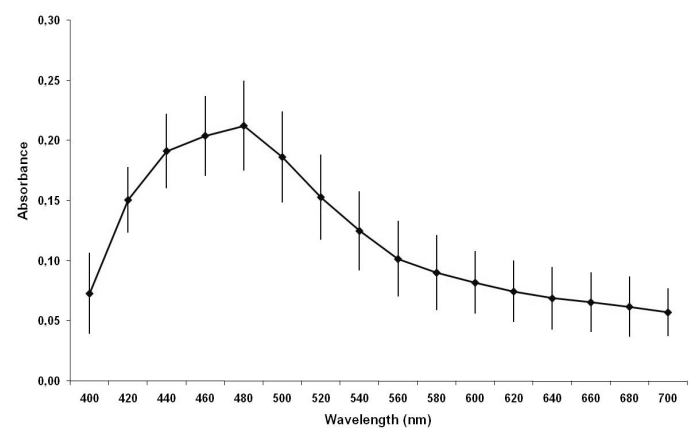

Figure 1 - Absorbance spectrum of an aqueous walnut extract.

Figure 2 shows the growth curve of $E$. coli AB 1157 cultures treated in presence or absence of walnut extract during 7 hours. The data suggest an alteration on the growth of $E$. coli incubated with walnut extract at the used concentration
(5 and $0.31 \mathrm{mg} / \mathrm{ml}$ ).

The electrophoretic profile of pBSK plasmid DNA in different experimental conditions is shown in figure 3. In lane 1 , the plasmid DNA alone is found mostly as a supercoil form (form I). In lane 
2 is shown the effect of $\mathrm{SnCl}_{2}$ on plasmid DNA indicating strand break and the presence of open circle form (form II). Lanes 3 to 5 show the electrophoretic profile of plasmid DNA incubated with walnut at different concentrations $(5,0.5$ and
$0.05 \mathrm{mg} / \mathrm{ml}$ ) suggesting no modifications in plasmid topology when compared with control (lane 1). In lanes 6 to 8 is shown that walnut extract seemed to potentialize the stannous chloride action due increase of open circle form.

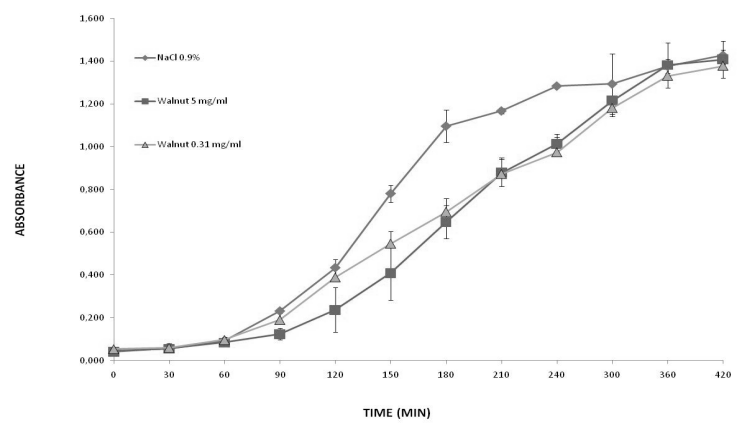

Figure 2 - Growth curve of Escherichia coli AB1157 in the presence of walnut extract (5 and $0.31 \mathrm{mg} / \mathrm{ml})$.

Table 1 presents the effects of walnut on the radioactivity distribution between cellular and plasma compartments. This data indicates alteration $(p<0.05)$ of ${ }^{99 \mathrm{~m}} \mathrm{Tc}$ distribution in these compartments.

Table 1 - Effect of walnut extract on the radioactivity distribution on the cells and plasma compartments labeled with ${ }^{99 \mathrm{~m}} \mathrm{Tc}$.

\begin{tabular}{ccc}
\hline Walnut $(\mathbf{m g} / \mathbf{m l})$ & \multicolumn{2}{c}{ \%ATI } \\
\cline { 2 - 3 } & \multicolumn{2}{c}{ B } \\
\hline 0.0 & $6.47 \pm 2.48$ & $93.53 \pm 2.48$ \\
0.31 & $6.06 \pm 3.82$ & $93.94 \pm 3.82$ \\
0.62 & $25.53 \pm 2.28$ & $74.47 \pm 2.28^{*}$ \\
1.25 & $43.22 \pm 7.27$ & $56.78 \pm 7.27^{*}$ \\
2.5 & $67.56 \pm 5.32$ & $32.44 \pm 5.32^{*}$ \\
5.0 & $72.31 \pm 3.05$ & $27.69 \pm 3.05^{*}$ \\
\hline
\end{tabular}

$*(P<0.05)$

\section{DISCUSSION}

Free radicals have been related to the primary destructive intermediates molecules in a wide range of environmental conditions, as well as these species are involved in various biological phenomena, as mutagenesis, apoptosis e aging (Ozben, 2007).

Cytotoxic and genotoxic effects of $\mathrm{SnCl}_{2}$ have been demonstrated in different experimental models and these appeared to be mediated by free radicals (El-Demerdash et al, 2005; Almeida et al, 2007). Moreno et al. (2004) related that an extract of Ginkgo biloba protected the plasmid DNA from the lesions induced by $\mathrm{SnCl}_{2}$. Our results with a walnut extract indicated that this extract has inhibited the growth of a $E$. coli culture (Figure 2) and has also potentialized the action of the $\mathrm{SnCl}_{2}$ on plasmid DNA (figure 3). Moreover, walnut (alone) was not also capable to induce modifications on DNA mobility in agarose gel.

Blood constituents labeled with ${ }^{99 \mathrm{~m}} \mathrm{Tc}$ have been used in several clinical examinations (Saha, 2004) and also as an experimental assay to verify the effect of drugs on radiopharmaceuticals (Fonseca et al., 2007). This experimental model has permitted the obtaining of relevant information about properties of various chemical compounds (Benarroz et al., 2008). The data obtained in this work indicates that there was a significant $(P<0.05)$ alteration on the distribution of the radioactivity on blood cell compartment (Table 1) 
on the presence of the walnut extract. Putting together these findings is possible to suggest that

the walnut extract has substances with redoxi properties

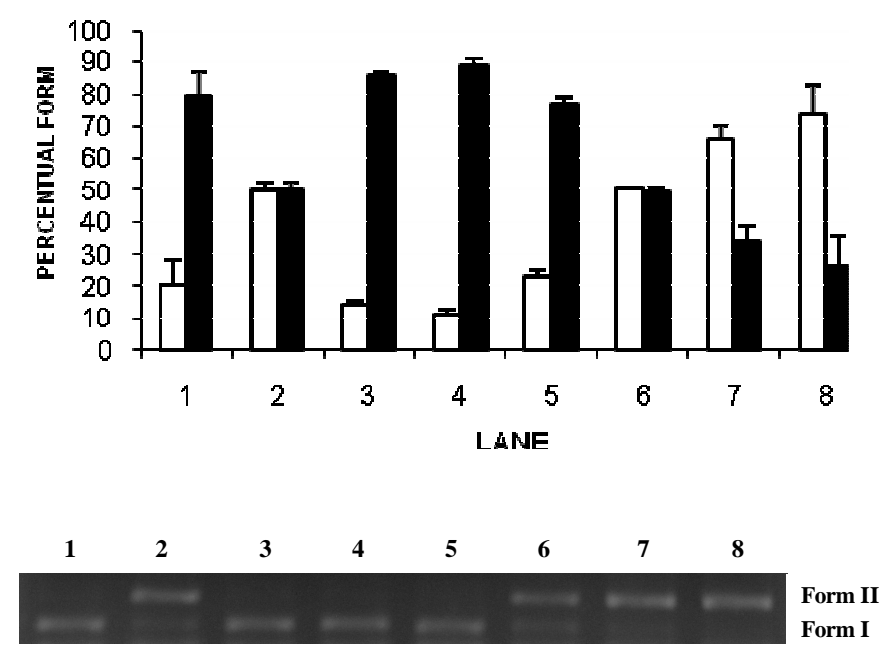

Figure 3 - Agarose gel electrophoresis of pBSK Plasmid DNA (200ng) treated with different concentrations of walnut, alone or associated with stannous chloride $(200 \mu \mathrm{g} / \mathrm{ml})$. Lane 1: control; Lane 2: stannous chloride $(200 \mu \mathrm{g} / \mathrm{ml})$; Lane 3: walnut $(0.05 \mathrm{mg} / \mathrm{ml})$; Lane 4: walnut $(0.5 \mathrm{mg} / \mathrm{ml})$; Lane 5: walnut $(5 \mathrm{mg} / \mathrm{ml})$; Lane 6 : walnut $(0.05 \mathrm{mg} / \mathrm{ml})$ and stannous chloride $(200 \mu \mathrm{g} / \mathrm{ml})$; Lane 7 : walnut $(0.5 \mathrm{mg} / \mathrm{ml})$ and stannous chloride $(200 \mu \mathrm{g} / \mathrm{ml})$; Lane 8 : walnut $(5 \mathrm{mg} / \mathrm{ml})$ and stannous chloride $(200 \mu \mathrm{g} / \mathrm{ml})$; Form I: DNA supercoil ( $\square$ ); Form II: open circle (匹).

Moreover, these results are in agreement of Pereira et al. (2008) that reported that walnut extracts have been exhibited antioxidant capacity in a concentration-dependent manner in an antimicrobial capacity assay against gram positive (Bacillus cereus, Bacillus subtilis, Staphylococcus aureus) and gram negative bacteria (Pseudomonas aeruginosa, Escherichia coli, Klebsiella pneumoniae) and fungi (Candida albicans, Cryptococcus neoformans).

In conclusion, our experimental data suggest that in the valnut extract has substances with an effect on the growth of E.coli culture, a potential action to increase the $\mathrm{SnCl}_{2}$ effect on plasmid DNA and also is capable to alter the distribution of ${ }^{99 \mathrm{~m}} \mathrm{Tc}$ on the blood cell compartment probably due to redoxi properties. Further studies will be performed to try to elucidate the action mechanisms involved in the effects of walnut extract obtained in this work.

\section{ACKNOWLEDGMENTS}

FAPERJ, CNPq, CAPES and UERJ supported this work.

\section{RESUMO}

O objetivo desse trabalho foi estudar a influência de um extrato de nogueira (Juglans regia) no crescimento de Escherichia coli (E. coli) AB1157, na topologia do DNA plasmidial e na marcação de constituintes sanguíneos com tecnécio-99m $\left({ }^{99 \mathrm{~m}} \mathrm{Tc}\right)$. Uma cultura de E. coli AB1157, em fase estacionária, foi incubada com nogueira e $o$ crescimento da cultura foi avaliado por densidade óptica a 600nm por 7 horas. Amostras de DNA plasmidial foram incubadas com $\mathrm{SnCl}_{2}$ na presença ou ausência de nogueira por 40 minutos, a eletroforese em agarose $0.8 \%$ foi realizada, o gel foi corado e as formas topológicas do plasmídio foram visualizadas. Amostras de sangue de ratos Wistar foram incubadas com extrato de nogueira e um ensaio de marcação de constituintes sanguíneos com tecnécio- $99 \mathrm{~m} \quad\left({ }^{99 \mathrm{~m}} \mathrm{Tc}\right)$ foi realizado. Células sanguíneas e plasma foram separadas. A radioatividade em cada fração foi contada e a percentagem de radioatividade incorporada (\%ATI) foi determinada. Os resultados apresentaram uma ação inibitória do crescimento da cultura de E. coli AB1157, 
nenhuma ação protetora do extrato de nogueira em DNA plasmidial tratado com $\mathrm{SnCl}_{2}$. Além disso, na nogueira também não foi capaz de induzir modificações na mobilidade do DNA em gel de agarose, mas a nogueira foi capaz de diminuir a distribuição de ${ }^{99 \mathrm{~m}} \mathrm{Tc}$ no compartimento sanguíneo celular. Concluindo, nosso resultado experimental sugere que no extrato de nogueira existem substâncias com um efeito no crescimento de cultura de E. coli, uma ação capaz de aumentar o efeito do $\mathrm{SnCl}_{2}$ no DNA plasmidial e também ser capaz de alterar a distribuição de ${ }^{99 \mathrm{~m}} \mathrm{Tc}$ no compartimento sanguíneo celular provavelmente devido a propriedades redoxi.

\section{REFERENCES}

Almeida, M. C.; Soares, S. F.; Abreu, P. R.; Jesus, L. M.; Brito, L. C.; Bernardo-Filho, M. (2007), Protective effect of an aqueous extract of Harpagophytum procumbens upon Escherichia coli strains submitted to the lethal action of stannous chloride. Cell Mol Biol (Noisy-le-grand), 53, 923927.

Asgary, S.; Parkhideh, S.; Solhpour, A.; Madani, H.; Mahzouni, P.; Rahimi, P. (2008), Effect of ethanolic extract of Juglans regia L. on blood sugar in diabetesinduced rats. J Med Food., 11, 533-538.

Bao, M.; Lou, Y. (2006), Flavonoids from seabuckthorn protect endothelial cells (EA.hy926) from oxidized low-density lipoprotein induced injuries via regulation of LOX-1 and eNOS expression. $J$ Cardiovasc Pharmacol, 48, 834-841.

Bernardo-Filho, M.; Cunha, M. C.; Valsa, J. O.; Araujo, A. C.; Silva, F. C.; Fonseca, A. S. (1994), Evaluation of potential genotoxicity of stannous chloride: inactivation, filamentation and lysogenic induction of Escherichia coli. Food Chem Toxicol., 32, 477-479.

Bernardo-Filho, M.; Santos-Filho, S. D.; Moura, E. G.; Maiworm, A. I.; Orlando, M. M. C.; Penas, M. E.; Cardoso, V. N.; Bernardo, L. C.; Brito, L. C. (2005), Drug Interaction with Radiopharmaceuticals: a Review. Braz Arch Biol Technol., 48(special issue), 13-28.

Dantas, F. J.; de Mattos, J. C.; Moraes, M. O.; Viana, M. E.; Lage, C. A.; Cabral-Neto, J. B.; Leitão, A. C.; Bernardo-Filho, M.; Bezerra, R. J.; Carvalho, J. J.;

Caldeira-de-Araujo, A. (2002), Genotoxic effects of stannous chloride $(\mathrm{SnCl} 2)$ in $\mathrm{K} 562$ cell line. Food Chem Toxicol., 40, 1493-1498.

El-Demerdash, F. M.; Yousef, M. I.; Zoheir, M. A. (2005), Stannous chloride induces alterations in enzyme activities, lipid peroxidation and histopathology in male rabbit: antioxidant role of vitamin C. Food Chem Toxicol., 43, 1743-1752.
Hsieh, C. L.; Chen, C. L.; Tang, N. Y.; Chuang, C. M.; Hsieh, C. T.; Chiang, S. Y.; Lin, J. G.; Hsu, S. F. (2005), Gastrodia elata BL mediates the suppression of nNOS and microglia activation to protect against neuronal damage in kainic acid-treated rats. Am J Chin Med., 33, 599-611.

Infanger, D. W.; Sharma, R. V.; Davisson, R. L. (2006), NADPH oxidases of the brain: distribution, regulation, and function. Antioxid Redox Signal., 8, 1583-1596.

Kinoshita, N.; Hashimoto, K.; Yamamura, T.; Teranuma, H.; Koizumi, T.; Satoh, K.; Katayama, T.; Sakagami, H. (2005), Protection by antioxidants of copper-induced decline of proliferation and SOD activity. Anticancer Res., 25, 283-289.

Luria, S. E.; Burrous, J. W. (1957), Hybridization between E.coli and Shigella. J Bacteriol., 74, 461476.

Marcus, D. L.; Strafaci, J. A.; Freedman, M. L. (2006), Differential neuronal expression of manganese superoxide dismutase in Alzheimer's disease. Med Sci Monit., 12, BR8-14.

Moreno, S. R.; Freitas, R. S.; Rocha, E. K.; Lima-Filho, G. L.; Bernardo-Filho, M. (2004), Protection of plasmid DNA by a Ginkgo biloba extract from the effects of stannous chloride and the action on the labeling of blood elements with technetium- $99 \mathrm{~m}$. Braz J Med Biol Res., 37, 267-271.

Ozben, T. (2007), Oxidative stress and apoptosis: Impact on cancer therapy. J Pharm Sci [Epub ahead of print]

Papoutsi, Z.; Kassi, E.; Chinou, I.; Halabalaki, M.; Skaltsounis, L. A.; Moutsatsou, P. (2008), Walnut extract (Juglans regia L.) and its component ellagic acid exhibit anti-inflammatory activity in human aorta endothelial cells and osteoblastic activity in the cell line KS483. British J Nutr., 99, 715-722.

Pungartnik, C.; Viau, C.; Picada, J.; Caldeira-deAraujo, A.; Henriques, J. A.; Brendel, M. (2005), Genotoxicity of stannous chloride in yeast and bacteria. Mutat Res, 583, 146-157.

Sambroock, J.; Fritsch, E. F.; Maniatis, T. (1989), Extraction and purification of plasmid DNA. In: Molecular cloning. A laboratory manual. New York: Cold Spring Harbour Laboratory Press.

Spaccarotella, K. J.; Kris-Etherton, P. M.; Stone, W. L.; Bagshaw, D. M.; Fishell, V. K.; West, S. G.; Lawrence, F. R.; Hartman, T. J. (2008), The effect of walnut intake on factors related to prostate and vascular health in older men. Nutr J., 7, 13.

Tsuda, K.; Nishio, I. (2004), Modulation of endothelial function by walnuts and sex hormones. Circulation, 110, e73

Received: August 18, 2008 Revised: September 11, 2008 Accepted: September 25, 2008 